\title{
Walter Heape, FRS: a pioneer in reproductive biology. Centenary of his embryo transfer experiments*
}

\author{
J. D. Biggers \\ Laboratory of Human Reproduction and Reproductive Biology, and Department of Cellular and \\ Molecular Physiology, Harvard Medical School, Boston, MA 02115, USA \\ Keywords: Heape; embryo transfer; primate; oestrous cycle
}

\section{Introduction}

About 100 years ago, on 27 April 1890, Walter Heape transferred rabbit embryos from one mother to another. One animal became pregnant and delivered young from the transferred embryos. Thus the first mammalian embryo transfer experiment was successfully completed. In this paper, I describe these experiments in some detail and then analyse why they were done. I place this embryo transfer work in perspective as it relates to other contributions of this pioneer in reproductive biology.

The Heape family has been traced back to the eleventh century (Heape \& Heape, 1905). Walter Heape's father, Benjamin Heape, an entrepreneur, moved from England to Melbourne in the then Australian colonies as a young man and founded the very successful general merchant company of Heape and Grice. He returned with his wealth to Manchester, England, to take over the family textile business. Benjamin Heape eventually became a Director and Vice-Chairman of the Bank of Manchester, a city that was one of the most prosperous in England as the result of the Industrial Revolution.

Walter Heape was born in 1855, 3 years after his father returned from Australia. He was brought up at the family home in Prestwich, outside Manchester, and was taught by a private tutor until the age of 17 . He then was a student for one year at Owens College, later to become the University of Manchester. This institution had been set up by the wealthy citizens of Manchester to educate people about science, which was seen as a great potential benefit to their industries (Kargon, 1977). Walter Heape left Owens College to embark on a business career, presumably to follow his father. For 5 years Walter Heape worked for three firms: the first was concerned with rice and sugar milling, the second was a merchant firm and the third was a cotton spinning mill. In 1877 , however, his health broke down. After a long voyage to Australia, Heape returned to business briefly, but, at the age of 24 , abandoned it for health reasons and embarked on a scientific career.

I mention Heape's background because it may account for his many, wide-ranging interests, both scientific and commercial. Intermittently, Heape continued his involvement in business ventures. For 2 years he held the position of Chairman of the Board of the New Elkhorn Mining Company, an English investment company that had investments in silver mining in Leadville, Colorado, which he visited twice (New Elkhorn, 1900, 1901). He was very interested in the exploitation of science to benefit human welfare, as, for example, the breeding of domestic animals (Marshall \& Hammond, 1946; Harvey, 1954). He supervised the construction of the Plymouth Laboratory, which the Marine Biological Association had founded to serve the interests of the British fishing industry (Heape, 1887a). It was to become a centre of basic research comparable to the Stazione Zoologica at Naples and the Marine Biological Laboratory at Woods Hole, Massachusetts.

\footnotetext{
*Based on a lecture given at the Walter Heape Symposium held at the University of Guelph, Ontario, Canada, on
} 25 April 1990. 
Walter Heape wrote four books, two of which were concerned with fertility. In his first book, The Breeding Industry, published in 1906, he critized the British Government for not supporting the scientific study of animal breeding and improvement. The second book, published in 1913, was called Sex Antagonism and it dealt with male/female conflicts such as the women's suffrage movement, which was of great concern to men raised in a Victorian society. In 1914 he published Preparation for Marriage, one of a series of books on human reproduction and the family, sponsored by the Church of England (Heape, 1914). The final book was entitled Emigration, Migration and Nomadism (Heape, 1931). It was published posthumously, in 1931, after some editing by another pioneer of reproductive biology, F. Arthur S. Marshall. Heape's versatility is further illustrated by his activities after his retirement. During World War I he became interested in ballistics and was involved in the production of the Heape and Grylls machine for high-speed cinematography (Connell, 1926).

Walter Heape married Ethel Ruston in 1891. Her father, Joseph Ruston, was head of Ruston, Proctor \& Co., a large firm that manufactured agricultural machinery. He was Member of Parliament for Lincoln and High Sheriff for the County of Lincoln. Walter and Ethel Heape had three children, none of whom took up science as a career. The eldest son, Brian, was killed in World War I; the only daughter, Barbara, lived for most of her married life in Kenya. The youngest son, Rodney, also lived outside England and was a farmer.

\section{Embryo transfer experiments}

Walter Heape's embryo transfer experiments were done between 1890 and 1897, and the results were published in two papers in the Proceedings of the Royal Society of London, the first in November 1890 and the second in November 1897. Heape's first experiment is described as follows:

On 27th April, 1890, two ova were obtained from an Angora doe rabbit which had been fertilized by an Angora buck thirty-two hours previously; the ova were undergoing segmentation, being divided into four segments.

These ova were immediately transferred into the upper end of the fallopian tube of a Belgian hare doe rabbit which had been fertilized three hours before by a buck of the same breed as herself.

It may be well to mention here, I bought this Belgian hare doe some three months before; the man from whom I bought her bred her, and guaranteed her to be a virgin doe of about seven months old. During the time I had her, until the 27th April, she had never been covered by a buck of any breed, being kept always isolated from the various bucks in my rabbitry.

In due course this Belgian hare doe gave birth to six young - four of these resembled herself and her mate, while two of them were undoubted Angoras. The Angora young were characterised by the possession of the long silky hair peculiar to the breed, and were true albinoes, like their Angora parents.

Both presumed Angora offspring were males.

Heape was particularly concerned about establishing the parentage of the Angoras. In support of his claim he emphasized that a characteristic of all Angoras, swaying of the head from side to side, was observed in both the parents of the transferred embryos and the Angora offspring. $\mathrm{He}$ further stated that there was no sign of Belgian hare traits in the Angora young and that the Belgian hare young showed no likeness to their two foster-brothers. It is clear that Heape was unknowingly relying on the use of genetic markers. However, we should recall that this technique was not 
explicitly understood until 1909, when Castle and Phillips introduced it to study the effects of ovarian transplantation (Castle \& Phillips, 1909).

The details of Heape's operative procedure, which are not given in his 1890 paper, but in the 1897 paper, are of interest, since the transfer was done without placing the embryos in any foreign environment such as serum or a physiological saline during the transfer process. It must be remembered that the first mammalian physiological saline was not introduced until 1901, by Locke (Locke, 1901). The technique is described as follows:

The Belgian Hare doe is put under anaesthetic and stretched out on her stomach. A longitudinal incision, 2 in. long, is then made through the skin at a place 1.5 to $3.5 \mathrm{in}$. from the anterior end of the pelvis, and on a level with the ventral border of the lumbar muscles. A smaller incision is then made through the body-wall just ventral to the lumbar muscles, and the anterior end of the fallopian tube is readily found and pulled out through the opening with the help of a pair of forceps. The foreign ova are then taken out of their maternal fallopian tube on the point of a spear-headed needle, the foster mother's infundibulum is held open with a pair of forceps and the ova placed well within the anterior end of her fallopian tube; after pushing the latter gently back again and washing with some antiseptic solution, the wound is sewn up and dressed with colloidin and cotton-wool.

The technique for the recovery of embryos from the donor fallopian tube is identical to that used to remove ova from freshly isolated oviducts, which was taught to students in the laboratory course given in the Morphological Laboratory at Cambridge, England (Foster \& Balfour, 1883). The practical schedule describes the recovery and handling of the ova as follows:

With the aid of a lens it is frequently possible to distinguish the ovum or ova, through the wall of the oviduct. In this case cut a transverse slit into the lumen of the duct with a fine pair of scissors a little to one side of an ovum; press with a needle upon the oviduct on the other side of the ovum, which will glide out through the slit, and can be with ease transported upon the point of a small scalpel, or what is better spear-headed needle. In case the ovum cannot be distinguished in the oviduct by superficial observation, the latter must be slit up with a fine pair of scissors, when it will easily be seen with the aid of an ordinary dissecting lens.

Heape probably taught in this course, for in 1882 he was appointed Demonstrator to assist in the teaching of animal morphology (Cambridge University Reporter, 1883).

Heape's conclusion from his initial experiment is best summarized from a report of the initial work in his second paper:

The experiment seemed to me to show, as far as a single experiment could show, that a uterine foster-mother has no power of modifying the breed of her foster-children, and that her uterus during gestation and the nourishment she supplies to the embryo is analogous to a bed of soil with its various nutrient constituents.

It is widely assumed that the initial embryo transfer experiments described in 1891 were done in Cambridge. There is significant circumstantial evidence, however, that these experiments were done at Heape's family home at Prestwich near the northern suburbs of Manchester. Who's Who for 1928 states that Walter Heape was resident in Cambridge during two periods: 1879-86 and 1891-1906. In the interval between these periods, Heape went on an extended journey to the East including India (Heape, 1887c, 1894). It was soon after his return from India that the first embryo transfer experiments were done, a period when Walter Heape was working not at Cambridge, but in Manchester at a laboratory in his home (Heape \& Heape, 1905). Moreover, Heape acknowledged the assistance in the embryo transfer experiments of $\mathrm{Mr}$ Samuel Buckley, a well-known 
surgeon in the Manchester area. Buckley was honorary physician to the Manchester Northern Hospital for Diseases of Women and Children in the nearby Manchester suburb of Cheetham Hill and during his life was a president of the North of England Obstetrical and Gynaecological Society (Obituary, 1910). It seems unlikely that Buckley would have travelled to Cambridge to assist in Heape's experiments. Further evidence that Heape was resident at Prestwich during this time is that his applications for a Grant-in-Aid to the Royal Society (Fig. 1) to support research on reproduction in monkeys and his letter of application for the Balfour Studentship were both sent from Northwood, Prestwich (Heape, 1890b, c). The generally held belief that the first embryo transfer experiments were done in Cambridge is not surprising, since the paper presented to the Royal Society of London was introduced by Michael Foster, the founder of physiology of the University of Cambridge, and it stated that Heape was the Balfour Student there. This statement is misleading, however, since Heape was not notified of being elected to the Balfour Studentship until 1 October 1890 , only 13 days before he presented his work before the Royal Society, and approximately 6 months after his embryo transfer experiment.

19. Walter Heape $\ldots \ldots \ldots \ldots \ldots \mathfrak{f 1 0 0 .}$

Northwood, l'restwich,

Manchester.

1. Investigation of the phenomena of menstruation and orulation, and of the early stages of development of tho menkey; also, if material is available, 1 propose to study placentation.

I propose to use for these researches Mlacacus rhesus.

2. \pm 100 .

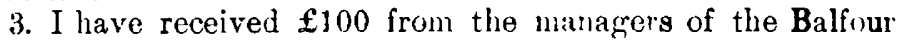
fund. There are no results. I have not yet received the necessary unimals.

I calculate that the cost of this research will be at least \&200. It will be necessary to use for the investigation adult monkeys; these are nut to be obtained from dealers in Fngland, and I have made arrangements to have them forwarded to ne direct from Calcutta.

4. No portion of the Grant will be used for personal expenses.

5. No apparatus is required. It will be necessary, however, to build an irou or wood shed or house in which to keep the animals.

$$
\text { [For Buard G also.] }
$$

Fig. 1. Summary of an application for a Grant-in-Aid made by Walter Heape to the Royal Society (Heape, 1890b).

Table 1. Summary of Heape's rabbit embryo transfer experiments; recipients were Belgian hare does

\begin{tabular}{lcccccc}
\hline Year & $\begin{array}{c}\text { Breed } \\
\text { transferred }\end{array}$ & $\begin{array}{c}\text { No. of } \\
\text { recipients }\end{array}$ & $\begin{array}{c}\text { No. of ova } \\
\text { transferred }\end{array}$ & $\begin{array}{c}\text { No. } \\
\text { pregnant* }\end{array}$ & $\begin{array}{c}\text { Native } \\
\text { young }\end{array}$ & $\begin{array}{c}\text { Transferred } \\
\text { young }\end{array}$ \\
\hline 1890 & Angora & 1 & 2 & 1 & 4 & 2 \\
1893 & Dutch & 4 & $?$ & 1 & 1 & 0 \\
1896 & Dutch & 4 & $?$ & 4 & 10 & 0 \\
1897 & Dutch & 5 & $?$ & 3 & 26 & 2 \\
\hline
\end{tabular}

*With one exception, the losses were due to death of the recipient under chloroform anaesthesia. 
Heape clearly recognized the limitations of an experiment on one animal, and he stated in 1891 that he intended to repeat the work. The experiment was not repeated for another 2 years, since his interest in reproduction in monkeys took him to Calcutta for a second visit. He returned to England in 1893 and took up residence in Cambridge. There he set up a rabbit colony where, among other things, he repeated the embryo transfer experiments. These were done during three seasons, in 1893, 1896 and 1897 (Table 1). The experiments in 1893 and 1896 failed to produce young from transferred embryos. Only in one transfer, in 1897, did Heape feel that he successfully confirmed the findings and conclusions of his original experiment done in 1890. Although Heape's embryo transfers were asynchronous, he was not aware that this may have influenced his chances of success.

\section{Explanation for the experiments}

In his first paper, Heape (1890a) asked three questions:

Is it possible to make use of the uterus of one variety of rabbit as a medium for the growth and complete foetal development of fertilized ova of another variety of rabbit?

What effect, if any, does a uterine foster-mother have upon her foster-children?

Does the presence and development of foreign ova in the uterus of a mother affect the offspring of that mother born at the same time?

Heape's final answers to these questions were given in his 1897 paper. He concluded:

That it is possible to make use of the uterus of one variety of rabbit as a medium for the growth and complete foetal development of fertilized ova of another variety of rabbit.

That the uterine foster-mother exerts no modifying influence upon her foster-children in so far as can be tested by the examination of a single generation.

Why did Walter Heape ask the three questions that led him to undertake these embryo transfer experiments? His first paper on embryo transfer is not explicit on this point. In retrospect we know that its success has implications for both basic and applied research and would be of use in animal breeding and clinical medicine. Although he was interested in animal breeding, particularly the use of artificial insemination (Heape, 1897c), there is no evidence of which I am aware that he at any time saw a practical application of embryo transfer. There is a suggestion, however, that he saw its potential in research on the analysis of the mechanisms of heredity. Four months after the first experiment, Heape wrote in his application for the Balfour Studentship (Heape, 1890c):

The success of this experiment, the first of its kind I believe, inclines me to believe that a new field of enquiry is thus opened to the student of problems connected with heredity.

The second and third questions need to be considered in terms of the biological debates of the time. The second half of the nineteenth century was a golden age in the biological sciences (see Jacob, 1982, for a review). It was a time when important theories were promulgated, in particular the theories of evolution, natural selection, and the continuity of the germ plasm. In the fields of growth and reproduction, exciting discoveries were made, such as the nature of fertilization and the existence of chromosomes and their behaviour in cell division. It was a time when a major schism occurred between those who thought that biology could only advance by the interpretation of natural history and animal morphology and those who saw the future in the application of the experimental method. It was also a time of controversy during which Darwinism underwent an eclipse (Bowler, 1983, 1989). Among these controversies were arguments about the mechanisms of heredity and whether inherited characters can be acquired. 
In 1868, Darwin had announced his 'provisional hypothesis of pangenesis' to explain inheritance. This complex hypothesis consisted of two main parts (Mayr, 1982). The first stated that the characters of organisms are associated with corpuscular elements, called gemmules, which are transmitted from one generation to the next. To explain the inheritance of acquired characters, the second part held that the hereditary material (gemmules) was carried by the blood from the tissues of the body to the reproductive organs. This proposal has been called the transportation hypothesis. Three years after Darwin introduced his ideas on pangenesis, Francis Galton attempted to test experimentally the transportation part of the hypothesis with his partial blood transfusion experiments in rabbits (Galton, 1871). In these experiments, the blood of one breed of rabbit was partially replaced by that of another breed. The recipient female was then mated to a buck of the same breed as herself. No characteristics of the donor animal were found in the offspring.

In 1874, a young Cambridge physiologist, George Romanes, began a series of experiments under the guidance of Charles Darwin using plants and animals to test whether acquired characters could be inherited. The experiments lasted several years but, because they failed, were not described until several years after Romanes' death (Romanes, 1895). Around 1876, Romanes attempted to obtain proof of the transportation hypothesis by grafting the ovaries of one breed of rabbit or dog into another and mating the recipient to a male of the same breed as herself. If any of the offspring had had characters similar to the recipient, evidence in favour of the inheritance of acquired characters would have been obtained. Since the grafts did not take, the experiments failed. Romanes then repeated Galton's experiment, totally replacing the blood. Again the offspring failed to exhibit donor characteristics.

When the theory of the 'continuity of the germ plasm' was published by Weismann in 1885 , it had a profound effect on the study of inheritance (Simpson, 1967; Bowler, 1983). The theory denied that the body is able to modify the genetic information passed on to the next generation. It thus polarized biologists into two camps: the neo-Lamarckians, who believed that acquired characters are passed on to future generations, and the neo-Darwinians, who unequivocally denied that acquired characters could be inherited. These two groups spent the next few years lambasting each other. It was in this intellectual cauldron that two individuals independently undertook embryo transfer experiments, Heape, probably in Manchester, and Romanes, in Oxford.

Romanes stressed that he undertook embryo transfer experiments to test whether acquired characters are inherited. His experimental design was similar to that of Heape's, although he used Himalayan and Belgian Hare rabbits, but his experiments did not lead to successful embryo transfers. Romanes stated that while he was doing his experiments he heard of the success of Heape. However he commented correctly that Heape made no claim in his 1890 paper to be testing any theory of inheritance.

Romanes abandoned his ovarian transplantation and embryo transfer studies when he became convinced, somewhat surprisingly, that, when two breeds of rabbit hybridize, no intermediate forms between the two parental forms are produced. As a result, he concluded that Galton's blood transfusion experiments, and his own, were ill-conceived and could not provide evidence one way or the other about the inheritance of acquired characters. He also stated that Heape's experiment was irrelevant to the issue. Later, Heape (1897a) replied to Romanes' criticism by claiming that Romanes' evidence that intermediate forms are never produced in the rabbit was untrue.

We do not know the strength of Heape's views on the inheritance of acquired characters. There is no doubt that he was a staunch supporter of Darwin's theory of natural selection. Whether he had read Weismann's theory of the continuity of the germ plasm, which ruled out absolutely the possibility of the inheritance of acquired characters, before doing his embryo transfer experiments in 1890, is unknown, but there is evidence that he was prepared to leave the question open. On 16 December 1887, Heape read a paper before the Plymouth Institution entitled, 'Recent proposed modifications of the Darwinian theory'. His paper reveals that he was aware of the criticism being levelled in the 1880s against Darwin's theory of natural selection (Bowler, 1983). In particular, he discussed the suggestion that isolation led to variation between individuals and eventually to 
speciation, as expounded by Dixon (1885), and the notion of physiological selection as proposed by Romanes (1886). However, Heape's remark that 'natural selection has been the main but not the exclusive means of modification' suggests that he may have been prepared to leave open, like Darwin several years earlier, the possibility of the inheritance of acquired characters. This suggestion is further supported by another remark made towards the end of the second paper on embryo transfer (Heape, 1897a):

It follows ... that in case telegony be actually demonstrated, the characteristics of a primary husband which are transmitted to the offspring got by a secondary husband, can only be so transmitted through the ovarian ova of the mother.

The word telegony requires some explanation. It was introduced in 1893 by Weismann, in a chapter entitled 'Doubtful phenomena of heredity', to refer to a belief that Darwin called 'the direct action of the male element on the female form' (Weismann, 1893). This belief was common folklore among animal breeders and, before the introduction of the word telegony, was called 'infection of the germ', 'foetal inoculation' or 'saturation' (Burkhardt, 1979). The belief first attracted the attention of scientists after the presentation of a paper to the Royal Society of London in 1821 by Lord Morton. He wrote:

I tried to breed from the male quagga and a young chestnut mare of seven-eights Arabian blood, and which had never been bred from; the result was the production of a female hybrid, now five years old, and bearing, both in her form and in her colour, very decided indications of her mixed origin. I subsequently parted with the seven-eights Arabian mare to Sir Gore Ouseley, who has bred from her by a very fine black Arabian horse. I yesterday morning examined the produce, namely a two-year-old filly and a year-old colt. They have the character of the Arabian breed as decidedly as can be expected, where fifteen-sixteenths of the blood are Arabian; and they are fine specimens of that breed; but both in their colour and in the hair of their manes they have a striking resemblance to the quagga. Their colour is bay, marked more or less like the quagga in a darker tint. Both are distinguished by the dark line along the ridge of the back, the dark stripes across the fore-hand, and the dark bars across the back of the legs.

In the United States of America the phenomenon was believed to occur in human beings. For example, Flint (1888), in his textbook on human physiology, wrote:

A peculiar and, it seems to me, an inexplicable fact is, that previous pregnancies have an influence upon offspring. This is well known to breeders of animals. If pure-blooded mares or bitches have been once covered by an inferior male, in subsequent fecondations the young are likely to partake of the character of the first male, even if they be afterwards bred with males of unimpeachable pedigree. What the mechanism of the influence of the first conception is, it is impossible to say; but the fact is incontestable. The same influence is observed in the human subject. A woman may have, by a second husband, children who resemble a former husband, and this is particularly well marked in certain instances by the colour of the hair and eyes. A white woman who has had children by a negro may subsequently bear children to a white man, these children presenting some of the unmistakable peculiarities of the negro race.

Many biologists of the time, including Darwin, believed that, if 'the male element can act directly on the female form', it would provide strong evidence for the inheritance of acquired characters. The question of telegony became of paramount importance after Weismann's enunciation of the theory of the continuity of the germ plasm, for telegony, if true, would require rejection of Weismann's theory. Weismann's main opponent, who believed strongly in telegony, was Herbert 
Spencer. Romanes (1899), who critically reviewed the Weismann/Spencer controversy, had some doubts about the existence of telegony, for he frequently qualified his remarks with the caveat 'should telegony be proved'.

In 1891, Romanes challenged Weismann for not discussing telegony when he proposed his theory of the continuity of the germ plasm (Romanes, 1899). Two years later, in 1893, Weismann rejected the occurrence of telegony. He wrote:

Such cases could only be accounted for from our point of view by supposing that spermatozoa had reached the ovary after the first sexual union had occurred, and had penetrated into certain ova which were still immature. The immediate fertilization of the latter is rendered inconceivable by the fact of their immaturity, and the sperm-cell must have remained in the body of the ovum until the maturation of the latter, with the nucleus of which it then united in the process of amphimixis. If this occurred sometime after the first of the offspring were born, it might easily have coincided approximately with the second coitus, from which fertilization would then apparently be due. If the 'infection' were proved beyond a doubt, a supplementary fertilization of an egg-cell in this manner must be considered possible; we certainly might then reasonably ask why mares, cows, or sheep, should not occasionally become pregnant without being covered a second time. But this has never yet been known to occur, and I incline to Settegast's view that there is no such thing as an 'infection' of this kind, and that all the instances which have been recorded and discussed critically by him are based upon a misconception.

When Walter Heape commented in November 1897 that telegony might come about by some ovarian mechanism, he clearly regarded the existence of telegony to be an open question. In January of that year Heape had been appointed a member of the Evolution Committee of the Royal Society of London (Royal Society, 1897). As a member of this committee, he almost certainly would have become familiar with the arguments involving telegony. Among the Committee's members was Ewart of the University of Edinburgh, who was involved in a long-term project in which the breeding experiment described by Lord Morton was being repeated as exactly as possible - the so-called Penycuik experiments (Ewart, 1899). There is no doubt that later Heape dismissed a physiological explanation of telegony, since he also rejected a similar explanation for maternal impressions, another related, doubtful phenomenon of heredity (Heape, 1913). Nevertheless, he continued to believe in the reality of the maternal impressions and sought an explanation in psychical forces.

Heape's demonstration that it was possible to transfer mammalian embryos from one mother to another had little immediate impact. Its first impact was, in fact, in the realm of scientific fiction. In 1924, J. B. S. Haldane gave lectures on the future of science, later published as Daedalus, before the Heretics Society of the University of Cambridge, in which he referred to Heape's embryo transfer experiments (Haldane, 1924). In one of these lectures, Haldane, fantasizing about the future of reproductive technology, placed himself in the twenty-first century and reported that the first ectogenetic mammal, a pig, was produced in 1940, and that the first ectogenetic child was produced in 1951. Eight years after Haldane's lectures the writer Aldous Huxley, following in this vein, wrote his novel Brave New World (Huxley, 1932). This was 2 years after Pincus reported his attempts in Cambridge to transfer rabbit embryos after in-vitro fertilization (Pincus, 1930; see Biggers, 1984, for a review). Soon after, embryo transfer began to be used as a tool in both basic science and animal science (Adams, 1982).

\section{Other interests in reproductive biology}

By focusing on Heape's embryo transfer experiments we should not conclude that this work was his main contribution. In fact, he made four other important contributions to reproductive biology: 
(i) the first detailed description of the uterine changes during the menstrual cycle in non-human primates (common langur and rhesus macaque: Heape, 1894, 1897b);

(ii) the formal description of reproductive cycles, including the language we use today to describe the oestrous cycle (Heape, 1900);

(iii) the epidemiology of infertility in farm animals, particularly sheep (Heape, 1899a, b); and

(iv) the discovery of nonspontaneous ovulation (Heape, 1905).

He also wrote extensively on the control of the sex ratio, but his contributions in this area are not particularly noteworthy (Heape, 1907, 1909).

Heape began studying science in Gamgee's physiological laboratory in Owens College, Manchester. He was there only a short time, going for a brief period to Oxford in Lawson's botanical laboratory and then to Cambridge. Heape arrived in Cambridge in 1879, where he studied with three of the scientific giants who launched the biological sciences at Cambridge after the breakaway from religious domination (Geison, 1978). These were Foster, Vines and Balfour, the fathers in Cambridge of physiology, botany and animal morphology, respectively. Balfour was the youngest of the trio - in fact, he was a student of Foster, who picked him to develop the study of embryology at Cambridge. Heape eventually joined Balfour's laboratory and began research into the littlestudied area of early mammalian development. Fellow students were William Bateson, who was destined to become Mendel's apostle in the English-speaking world (Punnett, 1928), and Henry Osborn, who later would become Director of the Museum of Natural History in New York (Osborn, 1883). Balfour was influenced strongly by Haeckel's biogenetic law and the writings of Lankester (1873). As a result, by the time Heape arrived in Cambridge, Balfour was fully convinced of the linkage between evolution and embryology. In an address to the British Association in 1880, Balfour argued that, as a consequence of the Darwinian laws of heredity and variation, every animal ought, in the course of its individual development, to repeat with more or less fidelity the history of its ancestral evolution (Foster \& Sedgwick, 1885). This belief is clearly the basis of his statement of the main objective of comparative embryology, made in 1881:

to test how far Comparative Embryology brings to light ancestral forms common to the whole of the Metazoa.

Heape worked in this intellectual atmosphere from 1879 to 1882 , concentrating with Balfour on problems in mammalian embryology. Specifically, he was concerned with the development of the germ layers of the rabbit (Balfour, 1881-82) and the early development of the European mole (Heape, 1881, 1883, 1886). The early embryos of the mole must have been hard to collect, because the animals have a very short breeding season and could not be bred in captivity. The species was chosen because insectivores were considered representatives of a primitive type.

Heape's work must have been severely interrupted because of the untimely death in 1882 of Balfour, who fell to his death on a mountain in Switzerland at the age of 32 years (Foster, 1882). Heape stayed on in Cambridge assisting Sedgwick as an instructor in the morphological laboratory that Balfour had founded. It was during this time, I suggest, that Heape wrote the appendix to the second edition of Foster \& Balfour's Elements of Embryology, published in 1883, which was a practical schedule for students on early mammalian development, using rabbit as the type species.

The death of Balfour may have released the Morphological Laboratory at Cambridge from its focus on the relation between evolution and embryology. The speculation inherent in this way of interpreting embryology was soon to be attacked by experimentalists. It is, therefore, not surprising that some of Balfour's students eventually abandoned his approach. Among these were his successor as Head of the Morphological Laboratory, Adam Sedgwick, and William Bateson (Sedgwick, 1909). It seems that Walter Heape also lost interest in this field, for he became involved with the newly formed Marine Biological Association at about this time.

The main priority of the Marine Biological Association was to raise money for a laboratory like the Stazione Zoologica in Naples to undertake the study of marine organisms. The justification for 
building the laboratory was to provide a scientific basis for improving the efficiency of the British fishing industry. Heape first became a fund raiser. The Minute Book of the Marine Biological Association (1885) records that at a meeting of the Council of the Association held on 13 May 1885 it was resolved:

that the chairman, Hon. Secretary and Treasurer be empowered to appoint an Assistant Secretary whose duty shall be to collect subscriptions for the Association, the said Assist. Sec. to receive a fixed salary not exceeding $£ 50$ and a percentage of $10 \%$ on all monies received through his individual exertions - as shall be agreed on with him by the above named officers.

At the same meeting, Walter Heape was appointed to this position. The terms of the resolution were not acceptable, however, since, at a meeting of the Council held one month later, the resolution was rescinded and a new resolution was adopted:

That Mr. Walter Heape be appointed assistant Secretary at a salary of $£ 100$ a year, the arrangement to be terminable by 3 months notice on either side.

The extent to which Heape raised funds is unknown. Soon after this meeting the Association decided to build its laboratory at Plymouth and on 14 December 1885 the Council appointed Heape to the position of Resident Superintendent to oversee its construction (Heape, 1887b). The Council also instructed Heape to conduct surveys of the fauna and flora in the waters near Plymouth, which he did thoroughly, as shown by the papers he published (Heape, 1887c, d). Clearly Heape had the applied aspects of his work at heart. Thus, in his final report to the Council he emphasized (Heape, 1887e):

the necessity of collecting and tabulating observations for some years before any attempt is made to generalize from them.

That accurate meteorological data and statistics of marine temperature, specific gravity, etc., will be absolutely necessary before it will be possible to understand, or, indeed, to consider at all such great questions as migration, distribution, and the daily and hourly movements of animals living at the surface and in mid-winter.

Perhaps at this time the first seeds were sown that would lead Heape into the systematic study of reproductive cycles.

On 1 September 1887, Heape sent a letter of resignation as the Superintendent of the Plymouth Laboratory (Heape, 1887f). His sudden resignation from the Plymouth Laboratory, before its inauguration, was due to serious policy differences with the Secretary of the Marine Biological Association, E. Ray Lankester. Despite occupying prestigious chairs in biology, Lankester wanted to be Director of the Laboratory (Dohrn, 1886). It also seems that he did not share Heape's practical approach to the research the laboratory should undertake. Heape was able to resign because he had independent means. The Plymouth Laboratory was opened at the end of June 1888, but Heape was not on the list of guests. He had left Plymouth in March 1888.

Heape then began an extended tour overseas, which lasted into 1889 , during which he visited Egypt, Ceylon, India, Burma and the Straits Settlements. In India he visited Calcutta and there developed an interest in the reproduction of the rhesus monkey. This new interest in primate reproduction was to have a profound effect on the direction of his career. On his return to England, Heape started to work, in his own words, on mammalian development and generation (Heape, 1890c). During this time he decided to focus on the early development of the monkey and applied for a Royal Society Grant-in-Aid (Heape, 1890b) and for a Balfour Studentship (Heape, 1890c), which had been set up by Balfour's friends and relatives in his memory. In his application for the Balfour Studentship, he stated that he would use the money to continue his work on transplantation of ova and to undertake studies on the embryology and sexual phenomena (e.g. 
menstruation) of monkeys. To do this he would need to use some funds to travel to Calcutta to collect material. He obtained both the Royal Society Grant and the Balfour Studentship and left for India in December 1890. In India he attempted to collect early embryos of two primate species: the common langur and the rhesus monkey. He soon found that collecting primate embryos was a formidable task. Unfortunately his stay in India was cut short by illness and after being there only 4 months he was advised to return to England. As a result, he obtained no early embryos of either species, but he was able to preserve many specimens of the female genital tracts of both. Over the next few years these specimens were sectioned and examined in detail. The result was a series of papers which for the first time provided a systematic account of the changes that occur in the uterus of a primate during the menstrual cycle (Heape, 1894, 1897b). His work resulted in an invitation to speak before the Obstetrical Society of London; in this talk, he compared the phenomenon of menstruation in monkeys and women (Heape, 1898).

Another important observation was made by Heape after he returned from India. In studies on rabbit breeding that he began in Cambridge in 1894 he noted that 'heat' alone was not sufficient to cause ovulation in virgin rabbits, but that, 9.5-11 h after copulation, ovulation invariably took place. In investigating this phenomenon Heape became interested in artificial insemination. As a result, he reviewed the subject in a paper published in the Proceedings of the Royal Society (Heape, $1897 \mathrm{c}$ ). One reviewer of this paper was Francis Galton. His comments are preserved in the archives of the Royal Society (Galton, 1897):

Originality in the strictest sense, is not the strong point of Heape's paper, but it seemed to me of eminent value as putting into an authoritative form a great quantity of material scattered far and wide, on a very interesting subject; and one of great importance to hybridising experiments, and of eminent value to horsebreeders.

The strictly original part is as yet imperfectly worked out, and little more than hinted at, namely that artificial impregnation is not apparently practicable in many animals, such as rabbits, because ovulation (according to his view) requires the excitement of the male, mere 'heat' and subsequent insemination artificially being not enough.

Eight years later, in 1905, Heape published the first description of nonspontaneous ovulation, which he investigated in rabbits.

Heape's encounter with artificial insemination marked the beginning of a major interest in animal breeding and the contribution that science could make to its improvement (Heape, 1906). As previously described, Heape was elected in 1897 a member of a newly established committee of the Royal Society of London called the Evolution Committee, which had been founded a few years earlier under the chairmanship of Francis Galton. The purpose of this Committee is stated in the following circular issued on 12 March 1897:

\section{Evolution Committee of the Royal Society}

This Committee has been appointed by the Council of the Royal Society to promote accurate investigations of Variation, Heredity, Selection and other phenomena relating to the Evolution of Plants and Animals.

Those who are engaged either in breeding the various races of domestic animals, or in scientific horticulture, have exceptionally good opportunities of making observations on the above subjects. In the course of their business attention is necessarily directed to the effects of various systems of breeding, to crosses between different species or varieties, to the transmission of parental characters, to the origin of new varieties, and to other facts of similar nature. Breeders and horticulturists are, in fact, continually engaged in experiments on a large scale, which, if they were recorded in detail, would have a high scientific value. 
The importance of such records as these is now generally admitted, and has been especially exemplified by the use Darwin was able to make of them in his writings, particularly in his Animals and Plants under Domestication ...

This appointment led to Heape's detailed field studies on the breeding of sheep and the extent of sterility in the species (Heape, 1899a, b). Throughout this work he stressed the importance of personally interviewing practical animal breeders in order to separate the wealth of valuable knowledge of these people from hearsay. In this he was practising what Darwin advocated half a century earlier (Darwin, 1868).

A strong case can be made that Heape's studies of the breeding efficiency of sheep, with his work on the menstruation of primates, finally led to what is, I believe, his most important paper. This paper, published in 1900 in the Quarterly Journal of Microscopic Science, was entitled 'The "sexual season" in mammals and the relation of the "pro-oestrum" to menstruation'. In this paper, Walter Heape introduced the language we use today to describe the several reproductive cycles. The words oestrum, proestrum, metoestrum, dioestrum and anoestrum were all introduced in this paper. His systematization of the subject rested solely on the interpretation of the natural history of reproduction in many mammalian species. Heape's terminology was immediately adopted by Marshall at the University of Edinburgh, another father of mammalian reproductive biology, in his classic descriptions of the oestrous cycle of sheep (Marshall, 1903), ferret (Marshall, 1904) and dog (Marshall \& Jolly, 1906). In the paper on the dog, Marshall \& Jolly pay tribute to Heape's work as follows:

We would like also to record our sense of obligation to Mr. Walter Heape, of Trinity College, Cambridge, who has done so much to further the subject under discussion.

\section{Conclusion}

Walter Heape's work was finally recognized by his being elected in 1906 a Fellow of the Royal Society of London. One year later he retired and left Cambridge. He lived another 22 years, during which time three of his four books were written. I hope I have shown that during his active scientific career he made several lasting contributions to reproductive biology, one of which it is appropriate for us to celebrate on its centenary.

I am particularly indebted to C. Kountz for skilled assistance in making library searches and in preparing this manuscript. I am also grateful to B. S. Williams for helpful criticisms of the manuscript.

I thank E. Denton, FRS, former Director of the Plymouth Laboratory, and the Council for permission to examine and quote from the Minute Book of the fledgling Marine Biological Association of the United Kingdom; C. Groeben, Archivist of the Stazione Zoologica, Naples, for providing access to correspondence between Walter Heape and Anton Dohrn; and R. J. Wolfe, Curator of Rare Books and Manuscripts, Francis A. Countway Library, and Joseph Garland, Librarian, Harvard Medical School. Valuable assistance has also been given by librarians of the Royal Society, London, the University Archives of Cambridge University and Trinity College, Cambridge.

Quotations from documents of the Royal Society are included by permission of the President and Council of the Royal Society.

\section{References}

Adams, C.E. (1982) Egg transfer: historical aspects. In Mammalian Egg Transfer, pp. 1-18. Ed. C. E. Adams. CRC Press, Boca Raton, FL.

Balfour, F.M. (1881-82) A Treatise on Comparative Embryology, vols I and II. MacMillan, London.
Biggers, J.D. (1984) In vitro fertilization and embryo transfer in historical perspective. In In Vitro Fertilization and Embryo Transfer, pp. 3-15. Eds A. Trounson \& C. Wood. Churchill Livingstone, London. 
Bowler, P.J. (1983) The Eclipse of Darwinism, pp. $20-43$. Johns Hopkins University Press, Baltimore.

Bowler, P.J. (1989) Evolution. The History of an Idea. Revised Edition. University of California Press, Berkeley.

Burkhardt, R.W. (1979) Closing the door on Lord Morton's Mare: the rise and fall of telegony. Stud. Hist. Biol. 3, 1-21.

Cambridge University Reporter (1883) May 18, p. 700.

Castle, W.E. \& Phillips, J.C. (1909) A successful ovarian transplantation in the guinea-pig, and its bearing on problems of genetics. Science, N.Y. 30, 312-313.

Connell, W.H. (1926) The Heape and Grylls machine for high speed photography. J. Sci. Instrum. 4, 82-87.

Darwin, C. (1868) The Variation of Animals and Plants under Domestication, ch. 27. Murray, London. 2 vols.

Dixon, C. (1885) Evolution without Natural Selection, p. 80 . Porter, London.

Dohrn, A. (1886) [Letter to E. Ray Lankester] 12 December 1886. Archives, Stazione Zoologica, Naples. 'A. Dohrn', ASZN: Ca IV.216.

Evolution Committee of the Royal Society of London (1897) Minutes of a meeting held 14 January 1897.

Ewart, J.C. (1899) The Penycuik Experiments. A. and C. Black, London.

Flint, A. (1888) A Text Book of Human Physiology, 4th edn, p. 797. Appleton, New York.

Foster, M. (1882) Francis Maitland Balfour. Nature, Lond. 26, 313-314.

Foster, M. \& Balfour, F.M. (1883) The Elements of Embryology, 2nd edn, p. 462. Eds A. Sedgwick \& W. Heape. Macmillan, London.

Foster, M. \& Sedgwick, A. (1885) The Works of Francis Maitland Balfour, vol. 1, pp.698-713. Macmillan, London.

Galton, F. (1871) On blood-relationship. Proc. R. Soc. Lond. 20, 394-402.

Gaiton, F. (1897) [Letter to Michael Foster] 5 March 1897. Archives, Royal Society, London.

Geison, G.L. (1978) Michael Foster and the Cambridge School of Physiology, pp. 244-249. Princeton University Press, Princeton.

Haldane, J.B.S. (1924) Daedalus or Science and the Future, pp. 63 68. Paul, Trench, Trubner and Co., London.

Harvey, N. (1954) Walter Heape and the British Stockbreeder. Agriculture 61, 381-385.

Heape, C. \& Heape, R. (1905) Records of the Family of Heape, of Heape, Staley, Saddleworth, and Rochdale from circa 1170 to 1905, pp. 267-270. Aldine Press, Rochdale, UK.

Heape, W. (1881) On the germinal layers and early development of the mole. Proc. R. Soc. Lond., B Biol. Sci. 33, 190-198.

Heape, W. (1883) The development of the mole (Talpa europa). The formation of the germinal layers, and early development of the medullary groove and notochord. $Q$. J. Micr. Sci. 23, 412-452.

Heape, W. (1886) The development of the mole (Talpa europa), the ovarian ovum and segmentation of the ovum. $Q$. J. Micr. Sci. 26, 157-174.

Heape, W. (1887a) Recent proposed modifications of the Darwinian Theory. Rep. Trans. Plymouth Institution 9, 389-391 (abstr.).
Heape, W. (1887b) Description of the Laboratory of the Marine Biological Association at Plymouth. $J$. Marine Biol. Assoc. 1, 96-104.

Heape, W. (1887c) Notes on the fishing industry of Plymouth. J. Marine Biol. Assoc. 1, 45-95.

Heape, W. (1887d) Preliminary report upon the fauna and flora of Plymouth Sound. J. Marine Biol. Assoc. 1, 153-193.

Heape, W. (1887e) Report of the Resident Superintendent, Plymouth Laboratory. J. Marine Biol. Assoc. 2, $142-152$.

Heape, W. (1887f) [Letter to the Honorary Secretary, Marine Biological Association] 1 September 1887. Marine Biological Association Minute Book. Archives of the Plymouth Laboratory.

Heape, W. (1890a) Preliminary note on the transplantation and growth of mammalian ova within a uterine foster-mother. Proc. R. Soc. Lond., B Biol. Sci. 48, 457-459.

Heape, W. (1890b) [Letter to the Royal Society of London] No date given.

Heape, W. (1890c) [Letter to the Secretary of the Balfour Memorial Fund] 26 September 1890. Archives, University of Cambridge.

Heape, W. (1894) XI. The menstruation of Semnopithecus entellus. Phil. Trans. R. Soc. Lond., B Biol. Sci. 185, $411-471$.

Heape, W. (1897a) Further note on the transplantation and growth of mammalian ova within a uterine foster-mother. Proc. R. Soc. Lond., B Biol. Sci. 62, $178-183$.

Heape, W. (1897b) The menstruation and ovulation of Macacus rhesus, with special observations on the changes undergone by the discharged follicle. Part II. Phil. Trans. R. Soc. Lond., B Biol. Sci. 188, 135-166.

Heape, W. (1897c) The artificial insemination of mammals and subsequent possible fertilization or impregnation of their ova. Proc. R. Soc. Lond., B Biol. Sci. 61, 52-63.

Heape, W. (1898) On menstruation of monkeys and the human female. Trans. Obstet. Soc. 40, 161-174.

Heape, W. (1899a) Note on the fertility of different breeds of sheep, with remarks on the prevalence of abortion and barrenness therein. Proc. R. Soc. Lond., B Biol. Sci. 65, 99-111.

Heape, W. (1899b) Abortion, barrenness and fertility in sheep. J. R. Agric. Soc., Ser. III 10, 1-32.

Heape, W. (1900) The 'sexual season' of mammals and the relation of the 'pro-oestrum' to menstruation. $Q$. J. Micr. Sci. 44, 1-70.

Heape, W. (1905) Ovulation and degeneration of ova in the rabbit. Proc. R. Soc. Lond., B Biol. Sci. 76, 260-268.

Heape, W. (1906) The Breeding Industry. Its Value to the Country and its Needs. Cambridge University Press, Cambridge, 154 pp.

Heape, W. (1907) Notes on the proportion of the sexes in dogs. Proc. Camb. Phil. Soc. 14, 121-151.

Heape, W. (1909) The proportion of the sexes produced by whites and coloured peoples in Cuba. Phil. Trans. R. Soc., B Biol. Sci. 200, 271-330.

Heape, W. (1913) Sex Antagonism. Constable, London, 217 pp. 
Heape, W. (1914) Preparation for Marriage. Cassel, London, $163 \mathrm{pp}$.

Heape, W. (1931) Emigration, Migration and Nomadism. Heffer, Cambridge, 369 pp.

Huxley, A. (1932; 1955) Brave New World. Penguin Books, Harmandsworth, UK.

Jacob, F. (1982) The Logic of Life. Transl. from French by Betty E. Spillman. Pantheon Books, New York, 348 pp.

Kargon, R.H. (1977) Science in Victorian Manchester. Johns Hopkins University Press, Baltimore.

Lankester, E.R. (1873) On the primitive cell-layers of the embryo as the basis of genealogical classification of animals, and on the origin of the vascular and lymph systems. Ann. Mag. Nat. Hist. 4, 321-339.

Locke, F.S. (1901) Die Wirkung der Metalle des Blutplasmas und verschiedener Zucker auf das isolierte Saugetierherz. Zentralbl. Physiol. 14, 670-672.

Marine Biological Association of the United Kingdom (1885) Minute Book 1.

Marshall, F.H.A. (1903) The oestrous cycle and the formation of the corpus luteum in the sheep. Phil. Trans. R. Soc., B Biol. Sci. 196, 47-96.

Marshall, F.H.A. (1904) The oestrous cycle in the common ferret. Q. J. Micr. Sci. 4, 323-345.

Marshall, F.H.A. \& Hammond (1946) The Science of Animal Breeding in Britain. The British Council, Longmans, Green and Co., London.

Marshall, F.H.A. \& Jolly, W.A. (1906) V. Contributions to the physiology of mammalian reproduction. Part 1. The oestrous cycle in the dog. Part II. The ovary as an organ of internal secretion. Phil. Trans. $R$. Soc. Lond., B Biol. Sci. 198, 99-141.

Mayr, E. (1982) The Growth of Biological Thought, pp. 693-698. Harvard University Press, Cambridge.

Morton, Lord (1821) A communication of a singular fact in natural history. By the Right Honourable the Earl of Morton, F.R.S. in a letter addressed to the
President. Phil. Trans. R. Soc. Lond., B Biol. Sci. 1, $20-22$.

New Elkhorn Mining Company. Anglo-Colorado Mining and Milling Guide (1900) 3, 188.

New Elkhorn Mining Company. Anglo-Colorado Mining and Milling Guide (1901) 4, 182.

Obituary (1910) Samuel Buckley, M.D. Lond. Lancet 1, 1793.

Osborn, H.F. (1883) Francis Maitland Balfour. Science, N.Y. 2, 299-301.

Pincus, G. (1930) Observations on the living eggs of the rabbit. Proc. R. Soc. Lond., B Biol. Sci. 107, 132-167.

Punnett, R. C., ed. (1928) Scientific Papers of William Bateson, pp. $2968,121-134,2$ vols. Cambridge University Press, Cambridge.

Romanes, G.J. (1886) Physiological selection. An additional suggestion on the origin of species. J. Linn. Soc. (Zool.) 19, 337-411.

Romanes, G.J. (1895) Darwin after Darwin, vol. II, pp. 145-148. Open Court Publishing Co., Chicago.

Romanes, G.J. (1899) An Examination of Weismannism, pp. 191-209. Open Court Publishing Co., Chicago.

Sedgwick, A. (1909) Influence of Darwin on the study of animal embryology. In Darwin and Modern Science, pp. 171-184. Ed. A. C. Seward. Cambridge University Press, Cambridge.

Simpson, G.G. (1967) The Meaning of Evolution, 2nd edn. Yale University Press, New Haven.

Weismann, A. (1885) Die Kontinuitat des Keimplasmas als Grundlage einer Theorie der Vererbung. Gustav Fischer, Jena.

Weismann, A. (1893) The Germ-Plasm. A Theory of Heredity, pp. 383-386. Trans. W. Newton Parker and H. Ronnfeldt. Scribner, New York.

Received 26 October 1990 